\title{
Coronavirus disease 2019 (COVID-19) complicated with acute myocardial infarction: etiology and nursing experience of three case reports
}

\author{
Yan Lei ${ }^{1 *}$, Yongxing Wang ${ }^{1 *}$, Yun Song ${ }^{1}$, Yue Cai ${ }^{2}$ \\ ${ }^{1}$ Department of Respiration, The First Affiliated Hospital of Air Force Medical University, Xian, China; ${ }^{2}$ Department of Cardiology, The First \\ Affiliated Hospital of Air Force Medical University, Xian, China \\ \#These authors contributed equally to this work. \\ Correspondence to: Yue Cai. Department of Cardiology, The First Affiliated Hospital of Air Force Medical University, 127\#Changle West Road, Xian \\ 710032, China. Email: caiyueclear1981@163.com.
}

\begin{abstract}
Coronavirus disease 2019 (COVID-19), an acute infectious disease, which is characterized by influenza, fever, cough and dyspnea. Up to now, the pathogenic mechanism and radical cure treatment for COVID-19 are still unknown. However, COVID-19 could lead to pneumonia, multiple organ failure and even death with disease development. During the period of February 10 and March 26, 2020, we admitted and treated three COVID-19 patients complicated with acute myocardial infarction. As we all know, acute myocardial infarction is a kind of disease that induces myocardial ischemia necrosis and leads to high mortality. Through the three COVID-19 patients complicated with acute myocardial infarction, we have strengthened our nursing experience. Thus, we wish to share our nursing experience with these cases by analyzing the etiology of three patients with coronavirus disease 2019 (COVID-19) complicated with acute myocardial infarction in this paper. First, we retrospectively analyzed the clinical data, including patient complaints, diagnosis, treatment, and prognosis, of three patients with COVID-19 complicated with acute myocardial infarction admitted to Ward II, Department of Infectious Diseases III, Huoshenshan Hospital, Wuhan, Hubei Province, China, between February 10 and March 26, 2020. Then, we searched for relevant literature, analyzed etiology, and summarized the nursing measures taken. For COVID-19 patients with a high risk of acute myocardial infarction, nurses should stay vigilant, closely monitor any change in condition, and implement early measures to maintain vital signs and enable timely visits with specialists. Finally, we importantly found that these nursing measures are keys to managing the patient's condition, improving patient outcomes, and increasing the chance of treatment success.
\end{abstract}

Keywords: Coronavirus disease 2019 (COVID-19); acute myocardial infarction; etiology; nursing; case report

Submitted Jan 21, 2021. Accepted for publication Jun 15, 2021.

doi: 10.21037/apm-21-1193

View this article at: https://dx.doi.org/10.21037/apm-21-1193

\section{Introduction}

Coronavirus disease 2019 (COVID-19) manifests as acute infectious pneumonia. Sequencing results confirmed that it is a novel $\beta$ coronavirus that is similar to severe acute respiratory syndrome coronavirus (SARS-CoV). The International Committee on Taxonomy of Viruses has named this virus SARS-CoV-2, and the World Health Organization has named the viral infection COVID-19. On
February 7, 2020, the National Health Commission decided to temporarily rename "pneumonia associated with novel coronavirus infection" as "novel coronavirus pneumonia". Previous studies found that COVID-19 could spread via air, droplets, contact, and gastrointestinal tract. What's more, COVID-19 is highly contagious for humans. Not only that, all age groups are susceptible and it shows family clustering and varied clinical manifestations (1-4). Although there 
have been many previous studies on COVID-19, this study is partly different from previous studies. In this research, we investigate coronavirus disease 2019 (COVID-19) complicated with acute myocardial infarction. Acute myocardial infarction (AMI) is the myocardial necrosis caused by acute and persistent ischemia and hypoxia of the coronary artery. Clinically accompanied by acute and persistent pain after the sternum and ultimately cause arrhythmia or heart failure. COVID-19 complicated with acute myocardial infarction could increase the degree of heart failure and affect the patient's life safety. Through the study of COVID-19 may be helpful in the treatment of acute myocardial infarction.

We admitted and treated three COVID-19 patients complicated with acute myocardial infarction between February 10 and March 26, 2020. Acute myocardial infarction is the myocardial necrosis caused by acute and persistent ischemia and hypoxia of the coronary artery. In recent years, the incidence rate of Acute myocardial infarction in China has been increasing year by year, and acute myocardial infarction is one of the most fatal diseases. Current autopsy and pathological data have shown irreversible degeneration and necrosis of myocardial cells, with a small amount of monocyte, lymphocyte, and/or neutrophil interstitial infiltration, as well as endothelial shedding, intimal inflammation, and thrombosis in some cases, which may lead to acute myocardial infarction. At present, there is no effective treatment for acute myocardial infarction.

Given the particularities of above all two diseases, we analyze the clinical data, diagnosis, and treatment of these three patients, explore their etiology, and summarize the nursing measures taken in the study. We present the following article in accordance with the CARE reporting checklist (available at https://dx.doi.org/10.21037/apm21-1193).

\section{Case presentation}

\section{General information}

Between February 10 and March 26, 2020, a total of three COVID-19 patients complicated with acute myocardial infarction were admitted to Ward II, Department of Infectious Diseases III, Huoshenshan Hospital, Wuhan, Hubei Province, China. All procedures performed in studies involving human participants were in accordance with the ethical standards of the institutional and national research committee(s) and with the Helsinki Declaration (as revised in 2013). Written informed consent was obtained from the patients. The patients had a mean age of 62 years (range, 57-67 years). All three patients were diagnosed as COVID-19, with underlying diseases such as hypertension, coronary heart disease, and type 2 diabetes. These three patients with acute myocardial infarction accounted for $0.12 \%$ of all COVID-19 patients admitted here during the same period. Importantly, the time of onset was 18,23 , and 22 days earlier compared to the patients without complications. Table 1 shows general information.

\section{Clinical information}

Among the three COVID-19 patients, one had mild symptoms and two had severe symptoms. After admission, all three patients received symptomatic care and nasal oxygen. Two patients took antiviral drugs. See Table 2 for details.

\section{Laboratory tests}

At the onset of symptoms of myocardial infarction, all three patients underwent laboratory tests immediately for myocardial injury markers, blood cell levels, and blood chemistry. The results showed significantly elevated myoglobin, high-sensitivity troponin I, creatine kinase, and creatine kinase isoenzyme (Table 3). Blood cell levels and blood chemistry were unremarkable (Table 4).

\section{Clinical information about acute myocardial infarction}

In all three cases, emergency bedside electrocardiogram (ECG) was abnormal, with varying degrees of relevant clinical manifestations. One patient had chest tightness with shortness of breath and profuse sweating that lasted a few minutes to 30 minutes. Two patients had chest tightness with profuse sweating and precordial pain at night that lasted a few minutes to 60 minutes. All of the patients' symptoms were relieved after increasing the oxygen concentration. See Table 5 for details.

\section{Treatment and outcome}

The three COVID-19 patients with acute myocardial infarction were detected early and treated promptly and effectively. After expert panel review, all met the discharge 
Table 1 General information

\begin{tabular}{|c|c|c|c|c|c|c|c|}
\hline Item & Sex & $\begin{array}{l}\text { Age } \\
\text { (years) }\end{array}$ & $\begin{array}{l}\text { Diagnosis at } \\
\text { admission }\end{array}$ & $\begin{array}{l}\text { Time of } \\
\text { onset }\end{array}$ & $\begin{array}{c}\text { Time of } \\
\text { discharge }\end{array}$ & $\begin{array}{l}\text { Diagnosis at } \\
\text { discharge }\end{array}$ & $\begin{array}{l}\text { History of past } \\
\text { illness }\end{array}$ \\
\hline 1 & Male & 63 & $\begin{array}{l}\text { 1. COVID-19 } \\
\text { 2. Hypertension grade } 2 \\
\text { (very high risk) }\end{array}$ & $10-F e b-20$ & 28-Feb-20 & $\begin{array}{l}\text { 1. COVID-19 } \\
\text { 2. Hypertension grade } 2 \\
\text { (very high risk) } \\
\text { 3. Coronary heart disease } \\
\text { 4. Acute myocardial infarction }\end{array}$ & $\begin{array}{l}\text { Hypertension, } \\
\text { coronary heart } \\
\text { disease }\end{array}$ \\
\hline 2 & Female & 67 & $\begin{array}{l}\text { 1. COVID-19 } \\
\text { 2. Hypertension grade } 2 \\
\text { (very high risk) } \\
\text { 3. Type } 2 \text { diabetes }\end{array}$ & $20-F e b-20$ & 14-Mar-20 & $\begin{array}{l}\text { 1. COVID-19 } \\
\text { 2. Hypertension grade } 2 \\
\text { (very high risk) } \\
\text { 3. Type } 2 \text { diabetes } \\
\text { 4. Acute myocardial infarction }\end{array}$ & $\begin{array}{l}\text { Hypertension, type } \\
2 \text { diabetes }\end{array}$ \\
\hline
\end{tabular}

Table 2 Clinical information of the three COVID-19 patients

\begin{tabular}{|c|c|c|c|c|c|c|c|c|}
\hline No. & $\begin{array}{l}\text { Symptoms at } \\
\text { admission }\end{array}$ & $\begin{array}{c}\text { Mental } \\
\text { state }\end{array}$ & Appetite & Sleep & $\begin{array}{l}\text { COVID-19 } \\
\text { RNA test }\end{array}$ & Chest CT & $\begin{array}{l}\text { Severity of } \\
\text { COVID-19 }\end{array}$ & $\begin{array}{l}\text { Main } \\
\text { treatments }\end{array}$ \\
\hline 1 & $\begin{array}{l}\text { Fever, cough, fatigue, } \\
\text { shortness of breath after } \\
\text { physical activity }\end{array}$ & Poor & Poor & Poor & $(+)$ & $\begin{array}{l}\text { Bilateral ground-glass } \\
\text { opacities }\end{array}$ & Severe & $\begin{array}{l}\text { Oxygen therapy, antiviral } \\
\text { therapy, symptomatic care }\end{array}$ \\
\hline 2 & Diarrhea, fatigue & Poor & Poor & Poor & $(+)$ & $\begin{array}{l}\text { Bilateral changes } \\
\text { consistent with viral } \\
\text { pneumonia }\end{array}$ & Mild & $\begin{array}{l}\text { Oxygen therapy, } \\
\text { symptomatic care }\end{array}$ \\
\hline 3 & $\begin{array}{l}\text { Chills, dry cough, wheezing, } \\
\text { fatigue, general muscle } \\
\text { aches }\end{array}$ & Poor & Poor & Poor & $(+)$ & $\begin{array}{l}\text { Bilateral multiple patchy } \\
\text { ground-glass opacities }\end{array}$ & Severe & $\begin{array}{l}\text { Oxygen therapy, antiviral } \\
\text { therapy, symptomatic care }\end{array}$ \\
\hline
\end{tabular}

criteria for COVID-19 per the current guidelines of the National Health Commission. They were transferred to the department of cardiology of local specialized hospitals in Wuhan for further treatment. See Table 6 for details.

\section{Nursing}

\section{Psychological intervention}

COVID-19 patients with acute myocardial infarction generally have a sense of immediate death due to acute onset, severe condition, and intense pain, as well as negative emotions such as fear, anxiety, and depression, which may aggravate their physical condition. Therefore, creating a good hospital environment provides comfort and accelerates patient recovery. During our daily work, nurses should familiarize themselves with various procedures, comfort the patients, explain disease-related information, build trust, help the patients plan for the future, and encourage them to build up their inner desires and the strength to survive. Moreover, nurses need to pay attention to how patients feel, develop a care plan, implement the plan after obtaining patient consent, and encourage the patients to actively engage in treatment and take personal responsibility, as well as affirm, acknowledge, and encourage their active 
Table 3 Laboratory test results of the three COVID-19 patients

\begin{tabular}{|c|c|c|c|c|c|c|c|c|}
\hline No. & $\begin{array}{l}\text { Myoglobin } \\
(\mathrm{ng} / \mathrm{mL})\end{array}$ & $\begin{array}{l}\text { High-sensitivity } \\
\text { troponin I } \\
(\mathrm{ng} / \mathrm{mL})\end{array}$ & $\begin{array}{c}\text { Aspartate } \\
\text { aminotransferase } \\
\text { (IU/L) }\end{array}$ & $\begin{array}{c}\text { Creatine } \\
\text { kinase (IU/L) }\end{array}$ & $\begin{array}{l}\text { Alpha hydroxybutyrate } \\
\text { dehydrogenase (IU/L) }\end{array}$ & $\begin{array}{l}\text { Creatine kinase } \\
\text { isoenzyme (IU/L) }\end{array}$ & $\begin{array}{c}\text { Lactate } \\
\text { dehydrogenase } \\
\text { (IU/L) }\end{array}$ & $\begin{array}{c}\text { BNP } \\
(\mathrm{pg} / \mathrm{mL})\end{array}$ \\
\hline 2 & 10.60 & 0.175 & 18.5 & 210.9 & 234.8 & 14.7 & 293.4 & 389.22 \\
\hline 3 & 25.55 & 2.932 & 8.30 & 253.4 & 276.6 & 28.7 & 312 & $1,644.69$ \\
\hline
\end{tabular}

Table 4 Laboratory test results of the three COVID-19 patients

\begin{tabular}{lccc}
\hline Item & Patient 1 & Patient 2 & Patient 3 \\
\hline White blood cells $\left(10^{9} / \mathrm{L}\right)$ & 7.2 & 6.4 & 4.0 \\
Lymphocyte percentage $\left(10^{9} / \mathrm{L}\right)$ & 11.5 & 23.6 & 42.6 \\
Absolute neutrophils $\left(10^{9} / \mathrm{L}\right)$ & 5.20 & 4.40 & 1.86 \\
Platelets $\left(10^{9} / \mathrm{L}\right)$ & 234 & 326 & 300 \\
Neutrophil percentage $(\%)$ & 72.3 & 69.3 & 46.8 \\
Absolute lymphocytes $\left(10^{9} / \mathrm{L}\right)$ & 0.83 & 1.50 & 1.69 \\
Red blood cells $\left(10^{9} / \mathrm{L}\right)$ & 3.79 & 3.61 & 4.11 \\
High-sensitivity C-reactive protein $(\mathrm{mg} / \mathrm{L})$ & 0.20 & 2.12 \\
Total protein $(\mathrm{g} / \mathrm{L})$ & 710.00 & 61.2 & 76.9 \\
Total bilirubin $(\mathrm{U} / \mathrm{L})$ & 56.9 & 9.8 & 13.8 \\
Creatinine $(\mu \mathrm{mol} / \mathrm{L})$ & 13.6 & 52.2 & 78.5 \\
Albumin $(\mathrm{g} / \mathrm{L})$ & 55.5 & 37.1 & 42.1 \\
Direct bilirubin $(\mathrm{U} / \mathrm{L})$ & 31.4 & 3.4 & 4.3 \\
Blood urea nitrogen $(\mathrm{mmol} / \mathrm{L})$ & 6.1 & 4.53 & 8.38 \\
Potassium $(\mathrm{mmol} / \mathrm{L})$ & 3.33 & 4.35 & 4.64 \\
Sodium $(\mathrm{mmol} / \mathrm{L})$ & 3.68 & 142.0 & 136.2 \\
Calcium $(\mathrm{mmol} / \mathrm{L})$ & 142.3 & 2.61 & 2.34 \\
Serum magnesium $(\mathrm{mmol} / \mathrm{L})$ & 1.96 & 0.92 & 0.85 \\
\hline
\end{tabular}

cooperation.

\section{Condition monitoring}

Absolute bed rest is a must. Depending on the severity of COVID-19 and the type of myocardial infarction, patients might need to be closely monitored for temperature, pulse, heart rate, blood pressure, oxygen saturation, and ECG changes. Blood test, blood chemistry, electrolytes, myocardial enzymes, troponin I, and coagulation should be monitored. Patients should be encouraged to work with their physician to enhance the treatment outcomes.

\section{Medication}

Patients should take medications exactly as directed by their physician, with double-checking and verification of the dosing schedule. Oral medications include antiplatelet therapy, lipid-lowering and plaque-stabilizing drugs, sedatives and analgesics, drugs to reduce oxygen consumption, drugs to suppress ventricular remodeling, and drugs for myocardial support. The intravenous drugs are mainly antiviral drugs. During treatment, patients should be closely monitored for treatment response, adverse reactions, and infusion reactions. An infusion pump or a micropump may be used to precisely 
Table 5 Clinical information about acute myocardial infarction

\begin{tabular}{|c|c|c|c|c|c|c|c|}
\hline No. & ECG & $\begin{array}{c}\mathrm{T} \\
\left({ }^{\circ} \mathrm{C}\right)\end{array}$ & $\begin{array}{c}\mathrm{P} \\
(\mathrm{bpm})\end{array}$ & $\begin{array}{l}\mathrm{R} \text { (breaths per } \\
\text { minute) }\end{array}$ & $\begin{array}{c}\mathrm{BP} \\
(\mathrm{mmHg})\end{array}$ & $\begin{array}{l}\mathrm{SpO}_{2} \text { without } \\
\text { oxygen (\%) }\end{array}$ & Clinical manifestations \\
\hline 1 & $\begin{array}{l}\text { ST elevation at } \\
\text { V2-V4 leads }\end{array}$ & 36.8 & 122 & 22 & $135 / 70$ & 96 & $\begin{array}{l}\text { Precordial pain, chest tightness, profuse } \\
\text { sweating at night that lasted a few to } \\
30 \text { minutes }\end{array}$ \\
\hline 2 & $\begin{array}{c}\text { Acute inferior ST } \\
\text { elevation }\end{array}$ & 36.4 & 102 & 21 & $150 / 91$ & 100 & $\begin{array}{l}\text { Chest tightness, shortness of breath, profuse } \\
\text { sweating, which was relieved slightly after } \\
\sim 30 \text { minutes of oxygen therapy }\end{array}$ \\
\hline 3 & $\begin{array}{l}\text { Acute inferior } \\
\text { posterior ST } \\
\text { elevation }\end{array}$ & 36.2 & 117 & 22 & $146 / 88$ & 99 & $\begin{array}{l}\text { Recurrent chest tightness, chest pain, } \\
\text { palpitations, profuse sweating at night, each } \\
\text { episode lasting a few to } 60 \text { minutes }\end{array}$ \\
\hline
\end{tabular}

ECG, electrocardiogram; BP, blood pressure.

Table 6 Clinical information after the onset of acute myocardial infarction

\begin{tabular}{|c|c|c|c|c|c|c|c|}
\hline No. & Emergency treatment & Main treatments & $\begin{array}{c}\text { Temperature } \\
\left({ }^{\circ} \mathrm{C}\right)\end{array}$ & $\begin{array}{l}\mathrm{SO}_{2} \\
(\%)\end{array}$ & $\begin{array}{c}\text { COVID-19 RNA } \\
\text { test }\end{array}$ & $\begin{array}{l}\text { Chest } \\
\text { CT }\end{array}$ & Outcome \\
\hline 1 & $\begin{array}{l}\text { Critical Condition } \\
\text { Notice sent, ECG } \\
\text { monitoring, absolute } \\
\text { bed rest, ongoing } \\
\text { monitoring of } \\
\text { myocardial enzymes } \\
\text { and myocardial injury } \\
\text { markers }\end{array}$ & $\begin{array}{l}\text { Oxygen therapy, coronary } \\
\text { dilation, antiplatelet therapy, } \\
\text { anti-coagulation therapy, } \\
\text { myocardial support, liver } \\
\text { protection, antiviral therapy }\end{array}$ & 36.8 & 96 & $(-)$ two times & $\begin{array}{l}\text { Signs absorption } \\
\text { of inflammation }\end{array}$ & $\begin{array}{l}\text { On day } 16 \text { after the } \\
\text { onset of symptoms, } \\
\text { the patient met the } \\
\text { discharge criteria } \\
\text { for COVID-19 and } \\
\text { was transferred to a } \\
\text { specialized hospital }\end{array}$ \\
\hline 2 & $\begin{array}{l}\text { Critical Condition } \\
\text { Notice sent, ECG } \\
\text { monitoring, absolute } \\
\text { bed rest }\end{array}$ & $\begin{array}{l}\text { Oxygen therapy, antiplatelet } \\
\text { therapy, anticoagulation } \\
\text { therapy, vasodilation }\end{array}$ & 36.4 & 100 & $\begin{array}{l}(-) \text { two times; } \\
\text { lgG antibody } \\
(+)\end{array}$ & $\begin{array}{l}\text { Significant } \\
\text { absorption and } \\
\text { improvement in } \\
\text { inflammation }\end{array}$ & $\begin{array}{l}\text { On day } 2 \text { after the onset } \\
\text { of acute myocardial } \\
\text { infarction, the patient } \\
\text { met the discharge } \\
\text { criteria for COVID-19 } \\
\text { and was transferred to a } \\
\text { specialized hospital }\end{array}$ \\
\hline 3 & $\begin{array}{l}\text { Critical Condition } \\
\text { Notice sent, ECG } \\
\text { monitoring, absolute } \\
\text { bed rest }\end{array}$ & $\begin{array}{l}\text { Oxygen therapy, antiviral } \\
\text { therapy, antiplatelet therapy, } \\
\text { lipid-lowering and } \\
\text { plaque-stabilizing, reducing } \\
\text { oxygen consumption, } \\
\text { suppressing ventricular } \\
\text { remodeling, myocardial } \\
\text { support }\end{array}$ & 36.2 & 99 & $(-)$ two times & $\begin{array}{l}\text { Significant } \\
\text { absorption of } \\
\text { inflammation }\end{array}$ & $\begin{array}{l}\text { Two days later, the } \\
\text { patient met the } \\
\text { discharge criteria } \\
\text { for COVID-19 and } \\
\text { was transferred to a } \\
\text { specialized hospital }\end{array}$ \\
\hline
\end{tabular}

ECG, electrocardiogram; IgG, immunoglobulin G.

adjust the infusion rate to prevent severe cardiac events due to cardiac overload resulting from a fast infusion rate.

\section{Diet management}

After nutrition assessment, a targeted nutrition plan should be developed based on patient needs, patient condition, and hospital supply. One patient was given a low-salt, lowfat, and low-cholesterol diet; two patients were given a lowsalt, low-fat, low-cholesterol, and diabetic diet. The diet was adjusted as needed based on glucose monitoring, and the patients were encouraged to have small, frequent meals. Oxygen therapy should not be interrupted. The diet should 
include egg, milk, soy products, vegetables, fruits, and rice noodles, as well as an oral enteral preparation as needed. Care was provided before, during, and after each meal and was recorded. Any fasting or delayed meal due to special circumstances was well communicated between shifts to ensure seamless care.

\section{Health education}

Nurses should educate patients about disease-related information and notify patients about their treatment and care plan to build their trust and encourage them to actively work with the healthcare team. After acute myocardial infarction, some patients become extremely worried about their condition. Once their condition and vital signs stabilize, patients should be encouraged to get up and resume appropriate activities as soon as possible to improve their physical condition and prevent other complications.

\section{Discussion}

COVID-19 is an epidemic respiratory disease which is characterized by dyspnoea, cough and nasal discharges and caused by a novel coronavirus (SARS-CoV-2). With the disease progress, COVID-19 could result in heart, kidneys, liver and multiple-organ injury. Previous study showed that it has higher mortality in elderly patients with underlying diseases, such as pulmonary disease, heart disease, kidney disease, diabetes, and hypertension (5). Three COVID-19 patients complicated with acute myocardial infarction between February 10 and March 26, 2020 were admitted. The patients were aged 62 years (mean) (range, 57-67 years), with underlying diseases such as hypertension, coronary heart disease, and diabetes. In this research, we explored the risk factors through analyzing the clinical data of three COVID-19 patients with acute myocardial infarction.

COVID-19 may lead to the activation of inflammatory cytokines and promote the release of interleukin- 6 and C-reactive protein. In addition, COVID-19 plays a vital role in the formation of atherosclerotic. A systemic inflammatory response upregulates the expression of cleavage proteins, thereby destabilizing plaques. While acute myocardial infarction is usually caused by a coronary atherosclerotic plaque rupture. Through the laboratory test results of the three COVID-19 patients, we found that COVID-19 is elevated relevant blood index, which is related to the formation of atherosclerotic.

In the context of chronic atherosclerotic vascular disease, infectious disease may cause acute coronary syndrome through acute inflammation, biomechanical stress, and vasoconstriction. Moreover, platelet activation and endothelial dysfunction may lead to thrombosis. Infections lead to higher metabolic demand and may cause hypoxemia, hypotension, or other vascular stresses, which can lead to thrombotic occlusion and then acute coronary syndrome (6). Acute respiratory infection may be associated with a higher risk of acute myocardial infarction $(7,8)$. Influenza and other respiratory viruses also enhance platelet activity, and acute infection promotes the development of acute coronary syndrome. All of these mechanisms increase the risk of myocardial infarction.

In conclusion, possible causes of acute myocardial infarction in COVID-19 patients with underlying diseases such as hypertension, diabetes, and coronary heart disease include COVID-19-related systemic inflammation, hypoxia, and coagulation disorders, which cause coronary contraction and ultimately lead to acute myocardial infarction. On the precaution of novel coronavirus, we should wear masks of good safety and effective protection seriously above all and often wash hands with soap or disinfectant. The most important thing is better not to go to crowded places. Residents should strictly abide by the epidemic prevention and control requirements in their current residences. Residents should travel less and better insulate their homes. What's more, residents keep their home environmental hygiene and don't participate in gathering activities. The government should pay more attention to the awareness of public health undertakings and clarify the responsibility at all levels departments. As an important part of public health, hospitals should strengthen public health construction to improve emergency management systems and ensure people's health. In addition to early detection and prompt treatment (including drug treatment), nurses should implement targeted, comprehensive, and holistic care. Physicians and nurses must work together to take effective measures to ensure successful treatment and patient safety and survival.

\section{Acknowledgments}

Funding: None.

\section{Footnote}

Reporting Checklist: The authors have completed the CARE reporting checklist. Available at https://dx.doi. org/10.21037/apm-21-1193 
Conflicts of Interest: All authors have completed the ICMJE uniform disclosure form (available at https://dx.doi. org/10.21037/apm-21-1193). The authors have no conflicts of interest to declare.

Ethical Statement: The authors are accountable for all aspects of the work in ensuring that questions related to the accuracy or integrity of any part of the work are appropriately investigated and resolved. All procedures performed in studies involving human participants were in accordance with the ethical standards of the institutional and national research committee(s) and with the Helsinki Declaration (as revised in 2013). Written informed consent was obtained from the patients.

Open Access Statement: This is an Open Access article distributed in accordance with the Creative Commons Attribution-NonCommercial-NoDerivs 4.0 International License (CC BY-NC-ND 4.0), which permits the noncommercial replication and distribution of the article with the strict proviso that no changes or edits are made and the original work is properly cited (including links to both the formal publication through the relevant DOI and the license). See: https://creativecommons.org/licenses/by-nc-nd/4.0/.

\section{References}

1. Chan JF, Yuan S, Kok KH, et al. A familial cluster of

Cite this article as: Lei Y, Wang Y, Song Y, Cai Y. Coronavirus disease 2019 (COVID-19) complicated with acute myocardial infarction: etiology and nursing experience of three case reports. Ann Palliat Med 2021;10(6):7107-7113. doi: 10.21037/ apm-21-1193 pneumonia associated with the 2019 novel coronavirus indicating person-to-person transmission: a study of a family cluster. Lancet 2020;395:514-23.

2. Rothe C, Schunk M, Sothmann P, et al. Transmission of 2019-nCoV Infection from an Asymptomatic Contact in Germany. N Engl J Med 2020;382:970-1.

3. Phan LT, Nguyen TV, Luong QC, et al. Importation and Human-to-Human Transmission of a Novel Coronavirus in Vietnam. N Engl J Med 2020;382:872-4.

4. Lu CW, Liu XF, Jia ZF. 2019-nCoV transmission through the ocular surface must not be ignored. Lancet 2020;395:e39.

5. Patel AB, Verma A. COVID-19 and AngiotensinConverting Enzyme Inhibitors and Angiotensin Receptor Blockers: What Is the Evidence? JAMA 2020;323:1769-70.

6. Corrales-Medina VF, Madjid M, Musher DM. Role of acute infection in triggering acute coronary syndromes. Lancet Infect Dis 2010;10:83-92.

7. Corrales-Medina VF, Musher DM, Wells GA, et al. Cardiac complications in patients with communityacquired pneumonia: incidence, timing, risk factors, and association with short-term mortality. Circulation 2012;125:773-81.

8. Kwong JC, Schwartz KL, Campitelli MA, et al. Acute Myocardial Infarction after Laboratory-Confirmed Influenza Infection. N Engl J Med 2018;378:345-53. 